\title{
Referaatopsommings
}

* Afdeling Biologie Jarkongres, 15-16 September 1999, Pretoria

\section{Genetiese variasie in mopanie}

\author{
L. Brand en M. van der Bank \\ Departement Plantkunde, Randse Afrikaanse Universiteit, Posbus 524, Auckland Park, 2006 \\ J.P. Grobler \\ Departement Dierkunde en Biologie, Universiteit van die Noorde, Privaat sak X1106, Sovenga, 0727 \\ D. Wessels \\ Departement Plantkunde, Universiteil van die Noorde, Privaat sak X1106, Sovenga, 0727
}

Colophospermum mopane (mopanic) het baic kommersiële toepassings, mar het veral bekendheid verwerf vanweë dic mopanicwurms wat dic blare vreet. Mopanic is deel van die familic Fabaceac, subfamilie Ceasalpinioideac en word gekarakterisecr deur skocnlappervormige blare, maar ook die tipiese groeivorm. Mopanic is verdeel in ekotipes en gevolglik kan genetiese differensiasic 'n rol speel by dic morfologiese verskille. Die hipotese dat mopanic spesiasic ondergaan het op evolusionêre vlak, is in die studic ondersock. 'n Populasiegerigte genetiese studic is op drie populasies van mopanic uitgevoer. Dic mees noordelike populasic, naamlik dic Messinaproefplaaspopulasic, dic mees suidelike populasic, naamlik dic Eilandpopulasie en 'n klein populasic van slegs 23 individue, wat net langs die Limpoporivier geleë is, is gekies vir hierdie studie. Horisontale styseljel-clektroforese op $12 \%$ jelle en $12 \%$ jelle wat $3,5 \%$ sukrose bevat, is vir hierdie doel benut. Ses buffersisteme en 18 ensiemkoderende loci het optimale resolusie gelewer. Dic rekenaarprogramme BIOSYS-1 en DISPAN, is benut om die data te verwerk. Die resultate het getoon dat die alleelverspreiding binne Hardy-Weinberg-proporsies val en gevolglik is hierdie populasies van mopanie geneties fiks. In hierdie studie is gevind dat die persentasie polimorfie rondom $30 \%$ vir al drie populasies is. Hierdie syfer is te verwagte, aangesien mopanie in uiterste klimaatstoestande voorkom. 'n Groot genetiese variasie binne die spesie sal aanpasbaarheid in gunstige toestande verseker en voortbestaan van die spesic aanhelp. Genetiese differensiasie word bepaal deur die Fst- waardes en in hierdie studie was hicrdic waarde 0.007 - wat dui op populasies van een spesic. Dic Fis-waardes is koëffisiënte van inteling, relaticf tot die subpopulasic waaraan dit behoort en word beïnvlocd deur nicwillekeurige kruising. Mopanic is ecnhuisige plante en gevolglik is inteling 'n groot waarskynlikheid. Die Fis-waardes vir hierdic studic is egter negatief en dus vind inteling glad nie plaas nic, maar die waardes dui eerder op ' $n$ meganisme van uitruiling van gene met ander populasies. Hierdie afleiding word versterk deur die negatiewe Fit-waardes, wat ook negaticf is vir hierdie studic. Fit-waardes is koëffisiënte van inteling relatief tot die totale populasic. Hierdie koëffisiënte word deur nicwillekeurige kruising, asook genetiese drywing beïnvloed. Gevolglik is daar heel moontlik 'n meganisme van buiteteling (buitekruising) betrokke. Hierdic meganisme van gecnuitruiling kan plaasvind deurdat stuifmeel deur wind, water of diere versprei word. Hierdie strategie is ontwikkel sodat inteling verhoed kan word en sodoende geneticse variasic te behou. Dic resultate dui dus daarop dat die mopaniepopulasies wat bestudecr is, populasies van een spesie is en dat die ekotipes se morfologiese verskille moontlik fenotipiese plastisiteit is. Hierdic hipotese moet egter getoets word deur middel van gekontrolecrde groei-cksperimente. Verdere bewyse vir die stelling dat mopanic een spesic is, is die genetiese afstandswaardes van $\mathrm{Nei}$ (1978 en 1972). Beide hierdie waardes is naby aan nul ( 0.000 en 0.003 , respekticwelik), wat bewys dat hierdie populasies deel is van een geenpoel. 


\title{
Genetiese variasie in mopaniewurms (Imbrasia belina) van verskeie ekotipes
}

\author{
M. Greyling en F.H. van der Bank
}

Departement Dierkunde, Randse Afrikaanse Universiteit, Posbus 524, Aucklandpark, 2006

J.P. Grobler

Departement Dierkunde en Biologie, Universiteit van die Noorde, Posbus X1106, Sovenga, 0727

Dic tekort aan 'n goedkoop, vocdsame vocdsclbron in Suid$\Lambda$ frika is tans een van dic land se grootste probleme, en in besonder die beskikbaarheid van 'n goedkoop, niebederfbare proteïenbron. Vir dic ongeskoolde landelike werker is armoede en ellende 'n alledaagse crvaring, maar met dic ontwikkeling van ons natuurlike hulpbronne, en in besonder mopaniewurms as 'n aanvullende voedselbron, kan hierdic probleem basies oorkom word. 'n Voorlopige elektroforeticse ondersock is uitgevoer op monsters van Imbrasia belina uit Noord-Botswana deur Riddoch en Solomon in 1996. Vier lokusse (GOT-1, PGM, PGI en IDH) van 17 ensiemsisteme is vir verdere studic gekies. Die resultate het getoon dat daar genocgsame variasic is om 'n grootskaalse studic te regverdig. Daar word beoog om in die huidige studie mopaniemot-bevolkings van verskillende ckotipes (Messina Proefplaas en Aventura Eiland) te bestudecr, en om vas te stel of daar genetiese verskille bestaan tussen die Desember- en Februaric-oeste. Geenprodukte van 19 proteïenkoderende lokusse is ondersock deur gebruik te maak van horisontale styseljel-clcktroforese. Voorlopige resultate toon heterosigositeitwaardes wat wissel tussen 17 en $23 \%$, en 'n gemiddelde polimorfiese waarde van $48 \%$. Die resultate dui dus op 'n groot variasic binne bevolkings, maar min differensiasic tussen bevolkings. Mopaniewurms is 'n belangrike proteïenbron in Suidelike Afrika, maar as gevolg van finansiële beperkings is daar min navorsing gedoen om hulle genetiese struktuur te ontleed. Sonder hierdie belangrike inligting kan geen sinvolle langtermynbestuur van dic hulpbron uitgevoer word nie. 